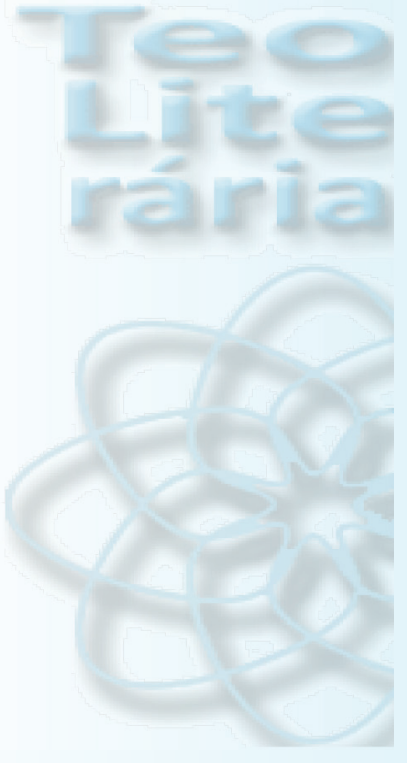

Texto enviado em

22.06.2019

e aprovado em

02.09.2016.

V. $9-$ N. $19-2019$

*Doutora em Ciências da Religião pela Pontifícia

Universidade Católica de São Paulo, Professora no Museu de Arte Sacra de São Paulo (MAS SP);

Professora e pesquisadora do LABÔ (Laboratório de

Política, Comportamento e Midia) PUC-SP

\section{A arte como expressão do sagrado: uma meditação sobre a liturgia e arte sacra.}

Art as an expression of the sacred: a meditation on liturgy and sacred Art.

\section{Wilma Steagall De Tommaso}

\section{RESUMO:}

Pelo Concílio Ecumênico Vaticano II, somos convidados a nos inspirar na arte e na arquitetura dos cristãos do Primeiro Milênio. Sob a premissa de que o simbolismo do templo cristão repousa na analogia que há entre o templo e o Corpo de Cristo, esta comunicação tem como objetivo entender como os cristãos, a partir do século IV, após o Edito de Milão em 313, conceberam a arquitetura e a arte nas paredes de seus templos. No Antigo Testamento (Êxodo 25), Moisés recebe de Deus a ordem de construir duas tendas, as duas são separadas por um véu, a Carta aos Hebreus ( $\mathrm{Hb} 8,9,10)$, retoma o pedido feito ao profeta, interpreta e explica toda a liturgia segundo a qual nasce o templo. A partir daí, demonstrar com citações e slides como eram decoradas interiormente as igrejas do Primeiro Milênio e entender sua coerência teológica, tendo como base textos bíblicos e conciliares, cartas dos papas Pio XII, Paulo VI, João Paulo II e Bento XVI. Expor a arte e a obra literária de dois artistas sacros contemporâneos: o brasileiro Cláudio Pastro (19482016) e o esloveno Marko Ivan Rupnik (1957), e colocar em foco as atribuições necessárias 
aos artistas da atualidade que se propõem a realizar esse trabalho nas igrejas.

Palavras-chave: Arte Sacra - Concílio Vaticano II - Primeiro Milênio Liturgia.

\section{ABSTRACT:}

By the Second Vatican Ecumenical Council, we are invited to take inspiration from the art and architecture of the Christians of the First Millennium. Under the premise that the symbolism of the Christian temple rests on the analogy between the temple and the Body of Christ, this communication aims to understand how Christians, from the fourth century, after the Edict of Milan in 313, conceived the architecture and art on the walls of their temples. In the Old Testament (Exodus 25), Moses receives from God the order to build two tents, the two are separated by a veil, the Letter to the Hebrews (Heb 8,9,10), takes up the request made to the prophet, interprets and explains all the liturgy according to which the temple is born. From there, demonstrate with citations and slides how the churches of the First Millennium were interiorly decorated and understand their theological coherence, based on biblical and conciliar texts, letters of the Popes Pius XII, Paul VI, John Paul II and Benedict XVI. To expose the art and literary work of two contemporary sacred artists: the Brazilian Cláudio Pastro (1948-2016) and the Slovene Marko Ivan Rupnik (1957), and put in focus the attributions necessary to the artists of the present time who propose to carry out this work in the churches.

Keywords: Sacred Art - Vatican Council II - First Millennium - Liturgy.

\section{Introdução}

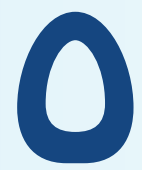

cristianismo nasceu no Oriente, na região da Palestina, porém, é no Ocidente do Império Romano - onde foi aceito após três séculos de existência - que acontece seu maior desenvolvimento. Roma é o centro da vida cultural e atrai todos os movimentos espirituais que se desenvolviam no século I. A Igreja cristã surge no auge do Império romano em um mundo cosmopolita e uma miríade de pessoas da Europa, África do Norte e Oriente Médio. 


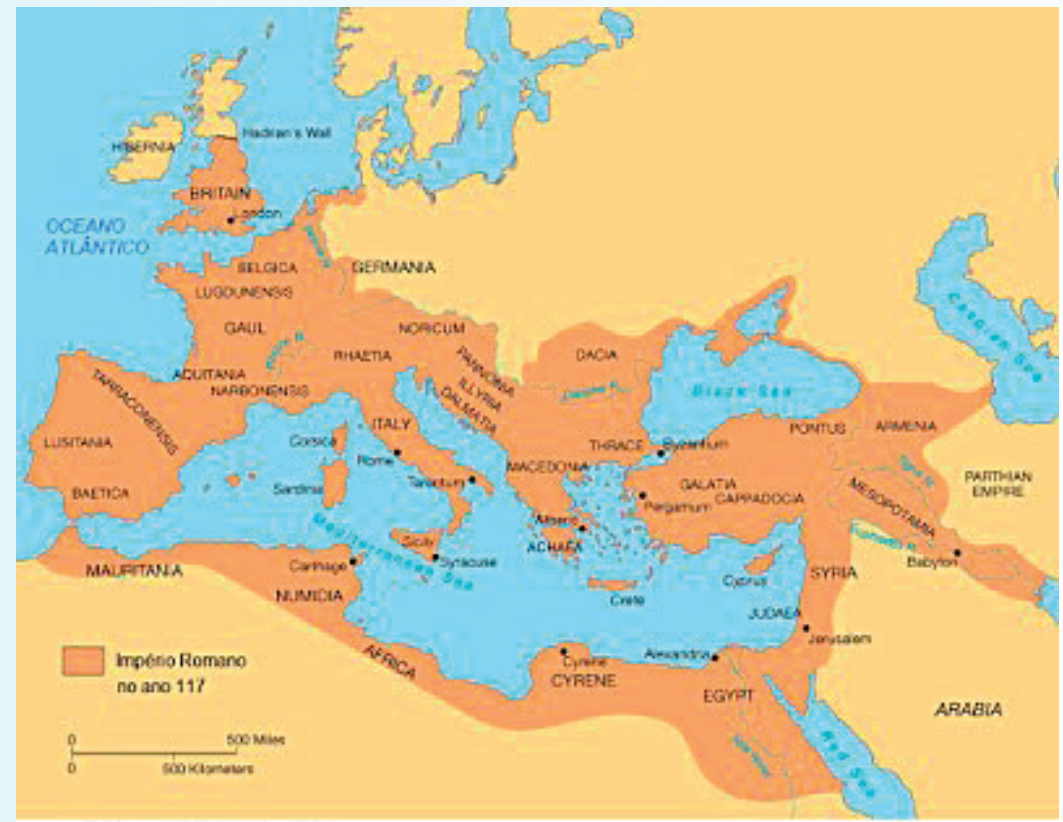

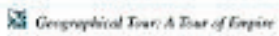

Figura I: Império Romano no ano 117.

Há dois milênios o movimento cristão entrou em um mundo onde havia muitas religiões, um universo diversificado em termos sociais e culturais, com muitas línguas, práticas religiosas, costumes diversos e uma infinidade de divergências culturais. O cristianismo nasceu como seita em um contexto em que Israel estava inserido no mundo dominado militarmente pelos romanos, porém, cultural e religiosamente, dominado pelos gregos. Esse povo diversificado, ao ouvir a mensagem dos apóstolos, não era uma página em branco, mas já trazia sua tradição e levava consigo suas ideias sobre a vida e a salvação quando aderiu à nova doutrina, o cristianismo.

Os cristãos primitivos assimilaram as práticas religiosas das culturas helenística e romana e com elas interagiram, porém, a maior herança veio da religião de Israel, cujo povo adorava ao Deus único e onde a interdição das imagens era ponto fora de discussão. 
A perseguição ordenada pelo imperador Nero no ano 64 conduziu ao martírio uma grande quantidade de cristãos. Os cristãos eram qualificados como ateus - negavam-se a prestar culto ao imperador -, perigosos para a unidade do império e inimigos do gênero humano; a eles se atribuíam as piores atrocidades: infanticídios, antropofagia e desordens morais de todo o tipo.

Com o Édito de Milão, promulgado pelos imperadores Constantino e Licínio em fevereiro de 313 , os cristãos não foram mais perseguidos, alcançou-se a paz, e ele puderam professar livremente a fé. É certo que as perseguições não tiveram sempre a mesma intensidade e que, excetuando alguns períodos, os cristãos seguiam suas vidas com normalidade; mas o risco de serem martirizados estava sempre presente. O martírio era considerado entre os fiéis um privilégio e uma graça de Deus: uma possibilidade de se identificar plenamente com Cristo no momento da morte. As relíquias dos mártires eram recolhidas e sepultadas com devoção e, a partir desse momento, recorria-se a eles como intercessores.

Tomas Spidlik nos aponta três dimensões da síntese espiritual e cultural que cristalizam com o nascimento da cristandade: a dimensão bíblica da fé judaico-cristã; a dimensão intelectual e conceitual da reflexão procedente da Grécia e a dimensão jurídica organizativa e programática procedente de Roma. Essas três dimensões, articuladas em um só organismo conceberam uma nova e inédita civilização¹.

\section{O império Romano e a cultura helênica}

Para entender o mecanismo central desta exposição, há que se recuperar o conceito de arte, harmonia e beleza na Grécia antiga.

A cultura helênica dá preferência à arquitetura e à escultura. Privilegia

1. Cf. Marko Ivan RUPNIK. La belleza, lugar del conocimiento integral. Disponível em http://comunicacioninstitucional. ufv.es/wp-content/uploads/2013/10/Lectio-DHCRupnik-.pdf. Acessado em 29 de jun. de 2018. 
o trabalho com o componente material: construção do espaço como espécie de devir do Cosmo do qual a arquitetura é um prolongamento. Impressionam as formas ideais, perfeitas, corpos com harmonia inexistente na natureza, templos com precisão óptica impecável. Há, portanto, o primado da ideia.

O pensamento grego testemunha uma certa divergência entre a ideia que representa a harmonia - portanto a eternidade - e a matéria, menos segura tanto em sua existência como em sua forma e sentido. $\mathrm{Na}$ civilização helênica o espaço entre esses dois mundos ficou sem solução. Foi a mitologia que criou pontes entre essas duas realidades, não a filosofia. Por isso o pensamento grego é trágico. Para evitar o aspecto trágico seria necessário fazer o corpo conforme a ideia: seria perfeito, tirá-lo da corrupção do futuro e da imperfeição. Os gregos desafiam a morte convencidos de que suas ideias permanecem: esta é sua mensagem unânime.

Precisamente sobre essa divergência abismal entre um mundo e outro é que surge a arte. Se não se pode passar de um mundo ao outro, com base no conhecimento, pode-se intervir no mundo, conformando-o à ideia, que por si só, reside nele. Assim como se distinguem diferentes escolas do pensamento, há também enfoques distintos sobre a arte grega, porém, substancialmente, esta era a questão. Há uma idealização, ou seja, se vê segundo a ideia, mas não só, corrige-se, embeleza-se e se aperfeiçoa sobre a base da ideia concebida.

Os cristãos entram no campo cultural e artístico governado pelo mundo greco-romano, ainda com um pouco de influência do Egito e da Síria. Porém, os cristãos não foram atraídos por essa arte. Sua arte, ao contrário, não buscava a perfeição formal, nem estética, mas queria de algum modo evocar uma memória viva, não de qualquer valor, ideia ou doutrina, mas de uma pessoa precisa, Jesus Cristo. Por isso, abandonam esse modo grego de fazer arte, tanto que sob o ponto de vista da perfeição da forma, a arte cristã é uma verdadeira decadência. A forma, 
entretanto, não lhes interessa, não porque não estejam a altura de realizá-la, mas porque a visão clássica não se afina com a fé cristã. É uma arte que procura fazer ver as coisas, a criação e a humanidade segundo o Cristo e não segundo uma ideia ${ }^{2}$.

\section{A arte das catacumbas}

\section{na contracorrente do Clássico greco-romano}

A arte cristã surge nas catacumbas, na contracorrente das grandes esculturas greco-romanas e apresenta o evento Cristo de modo a tornar compreensível a intervenção de Deus na humanidade. Essa arte cria um espaço onde o fiel contempla a unidade de tudo junto a tudo, como organismo vivo, pessoal, capaz de comunhão. No interior do organismo que é Cristo - significado de tudo - o fiel em sinergia com o Espirito Santo encontra a unidade do tudo ${ }^{3}$. Mas o povo que aderiu à nova doutrina já trazia sua tradição e suas concepções de vida e salvação:

Por mais que a mensagem do evangelho cristão exortasse seus ouvintes a romper com seu passado em ato radical de conversão, a prática era tomar contato com o mundo circunstante nas suas profundezas linguísticas e culturais. Para entender a história das igrejas cristãs primitivas, devemos, pois, ter em vista a diversidade dos ambientes sociais e culturais em que o movimento se espalhou 4 .

As catacumbas continham grafites, esboços, signos e símbolos. Os símbolos pagãos ganharam nova significação. O jardim, a palmeira e o pavão designam o paraíso terrestre; Hermes, símbolo da humanidade, representa o Bom Pastor. Há cenas do Antigo Testamento: Daniel e os leões, Adão e Eva. Ao fim do século II surgem símbolos de fato cris-

2. Cf. Natasa Govekar, curadora. II rosso della piazza d'oro: Intervista a Marko Ivan Rupnik su arte, fede ed evangelizzazione, p. 114-115.

3. Natasa Govekar, curadora. II rosso della piazza d'oro: Intervista a Marko Ivan Rupnik su arte, fede ed evangelizzazione 19-219.

4. Dale T. IRVIN; Scott W. SUNQUIST, História do movimento cristão mundial: do cristianismo primitivo a 1453 , v. I, p.73. 
tãos: multiplicação dos pães - o banquete eucarístico; adoração dos reis Magos - a entrada dos pagãos na Aliança; e símbolos compreendidos por poucos, como a vinha e o peixe, ichthys ${ }^{5}$. Tais signos são encontrados na Espanha, na Ásia Menor, da África até o Reno, em traços sumários e uma estrita gama de cores.

As imagens, não cultuais, retratam momentos do Cristo ou da Virgem $^{6}$. Como diz Evdokmov, nas catacumbas havia uma arte puramente significativa, didática, que proclama a salvação e traça seus instrumentos por meio de signos decifráveis, que:

Podem ser classificados em três grupos: 1) tudo o que se refere a água: a arca de Noé, Jonas, o peixe, a âncora; 2) tudo o que se relaciona com o pão e o vinho: a multiplicação dos pães, o trigo, a vinha; 3 ) tudo o que diz respeito à salvação e aos que foram salvos: os três jovens na fornalha, Daniel entre os leões, o pássaro fênix, Lázaro ressuscitado, o Bom Pastor. [...] Observase maior negligência na forma artística e ausência de um desenvolvimento teológico. O Bom Pastor não representa o Cristo histórico, mas quer dizer: o Salvador salva realmente ${ }^{7}$.

As pinturas das catacumbas mostram uma unidade de estilo e de temas: foram encontrados os mesmos símbolos na Ásia Menor, na Espanha, na África do Norte e na Itália, sem que a Igreja tenha dado uma indicação de um programa oficial. A fé manteve-se única, graças ao contato entre as igrejas locais. De acordo com Ouspensky:

A arte das catacumbas era, sobretudo, uma arte que visava o ensino da fé. Grande parte desses temas, tanto os simbólicos como os diretos, correspondem a textos sagrados do Antigo e Novo Testamento, textos litúrgicos e textos patrísticos. Paralelamente às representações diretas e muito numerosas, a linguagem simbólica se estendeu e desempenhou um papel fundamental na Igreja dos primeiros séculos. Essa linguagem simbólica

5. Do grego IX $\Theta Y \Sigma$ : lésous Chistós Théou Yós Sóter.

6. Cf. Alain BESANÇON, L'image interdite: une histoire intellectuelle de l'iconoclasme,

p. 206-207.

7. Paul EVDOKMOV, L'art de I'icône: théologie de la beauté, p. 149. 
a princípio é explicada pela necessidade de expressar pela arte uma realidade que não poderia ser expressa diretamente. Por outro lado, não revelar aos catecúmenos, até um certo momento, os sacramentos cristãos essenciais era uma regra estabelecida pelos Pais da Igreja e fundamentada sobre as Escrituras sagradas. Assim o sentido dos símbolos cristãos foi revelado aos catecúmenos progressivamente na preparação de seu batismo. Por outro lado, as relações entre os cristãos e o mundo exterior exigiam uma linguagem cifrada. ${ }^{8}$

Não havia interesse dos cristãos em divulgar ao mundo pagão e hostil os mistérios sagrados. Os primeiros cristãos empregaram antes os símbolos bíblicos: o cordeiro, a arca etc. Mas aos pagãos que entravam na Igreja, esses símbolos não bastavam, pois Ihes eram incompreensíveis. Então a Igreja adotou certos símbolos pagãos para reaproximá-los da "verdade" e transmitir diversos aspectos do ensinamento cristão. Esses símbolos foram direcionados, purificados e reencontraram seu significado, antes adulterados por uma longa degeneração, e serviram para exprimir a salvação consumada na encarnação ${ }^{9}$.

\section{Domus Ecclesiae}

Os cristãos reuniam-se, em sua origem, nas casas de alguns deles ou nas sinagogas dos membros que haviam se convertido à fé cristã. Porém, no século II, já tendo sido consumada a separação entre cristãos e judeus e, sobretudo, com o crescimento do número dos primeiros, estes adquiriam casas maiores, que pudessem abrigar toda a comunidade cristã e serem locais exclusivos de culto ${ }^{10}$.

As comunidades cristãs eram bastante grandes desde o fim do século I para poderem se reunir em casas particulares, pois precisavam de uma sala ampla com um altar, sob a presidência de um bispo. Em mea-

8. Léonide OUSPENSKY, La théologie de l'icône dans l'Église Orthodoxe, p. 43.

9. Ibid. p. 43.

10. JEDIN, Hubert. Manual de historia de la Iglesia I. Barcelona: Herder, 1966. p. 418419. 
dos do século II, a assembleia eucarística tinha se separado da refeição dos ágapes ${ }^{11}$ e havia se ritualizado em liturgia. ${ }^{12}$

Muitas casas foram construídas para esse fim, outras foram adaptadas, como as sinagogas. Nestas últimas, toda a vida litúrgica passou a ser realizada, uma vez que já se começava a não mais celebrar a Eucaristia durante uma refeição. O batismo, antes celebrado em lugares de água abundante, portanto, públicos, agora era celebrado em lugares privados, e muitas dessas sinagogas possuíam uma pequena piscina onde se praticava um banho ritual. Esses locais exclusivos de culto cristão ficaram então conhecidos como domus ecclesiae (casa da Igreja).

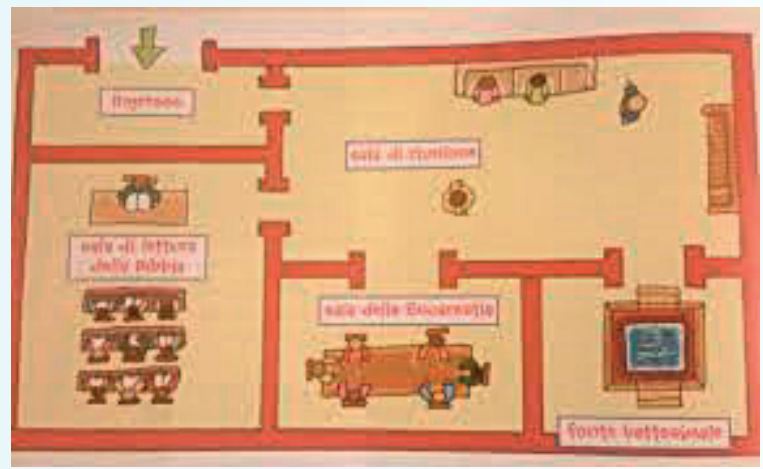

Figura 2: esquema de sinagoga adaptada para 0 uso dos cristãos.

Nesse período, o culto cristão não era centrado em imagem, mas no altar do sacrifício. O templo não se limitava à mesa com a estátua de um deus, mas reunia uma comunidade em torno do banquete sagrado. Os cristãos recusavam a imagem cultual, considerada expressão do culto pagão aos ídolos, como recusavam a imagem imperial, motivo pelo qual eram perseguidos. As imagens também contrariavam a Lei mosaica. A Igreja acabou aceitando a imagem no espaço cultual, não na forma de

11. Os cristãos deram o nome de ágape às refeições comunitárias distintas da eucaristia e acompanhadas de orações. Esse nome ágape é tomado do nome grego que designa caridade, cujo aspecto comunitário ele sublinha. (IN: LACOSTE, Jean-Yves. Dicionário crítico de teologia. Ágape, Pierre Marie GY. São Paulo: Paulinas, Loyola, 2004, p 66).

12. Cf. LACOSTE, Jean-Yves. Dicionário crítico de teologia. Arquitetura, Lynne BROUGHTON, p 186. 
estátuas, mas de pinturas. Isso se deu após discussões teológicas da natureza do Cristo, quando surge uma doutrina das imagens que justifica em retrospecto o uso cultual. Segundo Hans Belting, autores atuais retomam o argumento com o mesmo respeito dispensado ao ícone:

É assim que persiste o erro de acreditar que se tratava de uma interpretação originalmente cristã e originalmente intelectual da imagem, como se os cristãos tivessem tido uma relação clara, face a face das imagens cultuais de seus ancestrais pagãos. Mas não se deve deixar induzir por esse erro de uma doutrina apologética que sublima práticas existentes buscando uma justificativa teórica a posteriori. A doutrina dos ícones não pode então ser tomada tal qual, pois ela não deixa de ser um produto da controvérsia histórica em torno da imagem religiosa ${ }^{13}$.

Na liturgia da Domus Ecclesia, celebrava-se em volta da mesa, a prioridade era o cenáculo na forma do que era a Última Ceia, na qual Cristo mostra aos discípulos que Ele é o Dom, a Oferta do Pai, e se entrega nas mãos dos homens, para que esses "destruindo", comendo desse dom, descubram a bondade do Pai e voltem ao Pai. O sentido teológico da Última Ceia é o retorno ao Pai, esse era o espirito da liturgia doméstica dos primeiros cristãos. Pelo batismo o cristão se torna filho e na eucaristia retorna ao Pai e essa é a casa dos cristãos, a casa do Pai.

As primeiras imagens cristãs de que se tem conhecimento apareceram nas catacumbas, como exposto anteriormente. Essa arte funerária se revestia de alegria, pois, se a morte é inexorável, para os cristãos havia a certeza da ressurreição. De acordo com Ouspensky e Lossky,

As pinturas das catacumbas desde os primeiros dois séculos tinham como tema não somente alegorias e símbolos tais como a âncora, o peixe, o cordeiro, etc., mas toda uma série de imagens que vieram do Antigo e do Novo Testamento. Essas pinturas correspondem aos textos sagrados, bíblicos, litúrgicos, patrísticas. O princípio fundamental dessa arte é de exprimir por pinturas

13. Hans BELTING, Image et culte: une histoire de l'image avant l'époque de l'art, $p$. 193-194. 
a doutrina da Igreja, representando os acontecimentos concretos da História santa e indicando também o seu sentido. Essa arte não tem por fim refletir os problemas da vida, mas sim de respondê-los, assim desde a sua aparição ${ }^{14}$.

Nas casas ou nas catacumbas, os cristãos adotaram símbolos pagãos e lhes deram um significado mais profundo: o barco, símbolo da prosperidade e de uma travessia feliz pela vida, tornou-se o símbolo da Igreja; a entrada do navio em um porto não significa mais a morte, mas a paz eterna; os símbolos eróticos (Eros e Psique) tornaram-se a sede da alma pelo amor de Deus. Esses símbolos são o reflexo do ensinamento das verdades da fé. Por eles, os fiéis são conduzidos para um conhecimento mais profundo do cristianismo ${ }^{15}$.

A liturgia, embora ainda não esteja completa - o que irá acontecer na segunda metade do século IV - já se encontra em um estado de evolução bastante adiantado, bem como a hierarquia das Igrejas. Isso requereu das domus ecclesiae uma estrutura interna que permitisse o desenvolvimento dos ritos, acomodação dos ministros e da assembleia.

A partir do momento em que os cristãos deixam de celebrar nas casas e começam a celebrar em edifícios públicos, que eram muitas vezes mercados, pois homens poderosos se converteram e doaram imóveis para a celebração do culto cristão, os cristãos entravam e celebravam a liturgia, mas quando terminavam, percebiam que o espaço havia se transformado. A liturgia é transfiguração do mundo. O que acontece no altar acontece no cristão, e onde termina? Ninguém pode responder, é algo que penetra no mundo, é a cristificação, a transfiguração do mundo. Os cristãos entenderam que a liturgia muda o espaço, é propriamente a liturgia que modela o espaço e que se tornou a casa, a sua casa.

14. Léonide OUSPENSKY; Vladimir LOSSKY, Le sens des icônes, p. 25.

15. Cf. Alain BESANÇON, L'image interdite: une histoire intellectuelle de l'iconoclasme, p. 206-207. 


\section{Basílica paleocristã}

A partir do século IV a comunidade cristã obteve a liberdade de culto, iniciando a construção de edifícios para celebrar seus ritos que até o momento eram celebrados em casas privadas, como já descrito no item anterior.

Com o Édito de Milão de 313, o imperador Constantino não só concedeu aos cristãos liberdade de culto, mas deu ao Estado uma estrutura cristã, embora o cristianismo se tornasse religião oficial do Estado somente com o imperador Teodósio em fins do século IV.

A Igreja paleocristã se inspira na arquitetura romana e em particular na planta longitudinal da basílica. A basílica romana era uma adaptação da basílica helênica que chegou a Roma no século II a. C., com fins comerciais ou forenses.

Ecclesia Basilicalis" corresponde a construções grandiosas, concebidas para engrandecer a glória de Deus e para dar maiores espaços à crescente frequência dos fiéis. Basílicas essas que eram, no inicio, uma adaptação de locais romanos (fórum, senado, termas...) ou aproveitamento de materiais de edifícios e templos pagãos. ${ }^{16}$

A simetria da basílica romana se constata no fato de ela ter duas ordens de colunatas, uma frente à outra, e duas absides, também uma frente à outra, criando assim um centro precioso e único, função do edifício e não do caminho do homem ${ }^{17}$. $\mathrm{O}$ arquiteto cristão, por sua vez, suprime uma das absides e desloca a entrada para o lado menor e, desta forma, rompe a dupla simetria do retângulo, deixa o único eixo longitudinal e faz dele a diretriz do caminho do homem ${ }^{18}$. Os cristãos deram aos esquemas da basílica uma alma e uma função, de modo que o eixo se tornou uma metáfora "do caminho" que o homem deve percorrer rumo à parusia, representada pela abside única. Contudo, a basílica romana

16. PASTRO, Cláudio. A arte no cristianismo: fundamentos, linguagem, espaço. p. 262.

17. ZEVI, Bruno. Saber Ver a Arquitetura. São Paulo: Martins Fontes, p. 71.

18. Idem. 
só empresta aos cristãos a sua forma externa, porque internamente foi adaptada para a liturgia cristã.

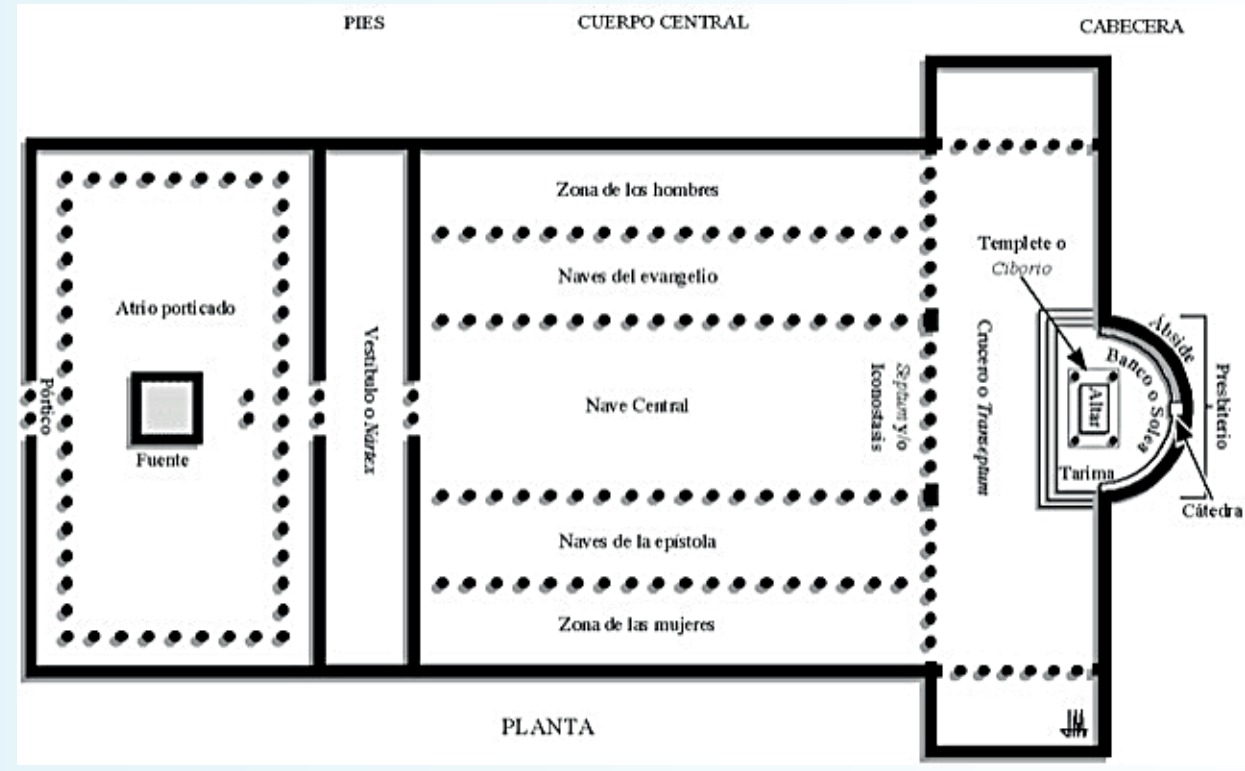

Figura 3: esquema da antiga Basilica de São Pedro em Roma.

As basílicas se multiplicavam por todo o Império, embora se conservassem também construções mais modestas, mas certamente para as igrejas episcopais adotava-se o estilo basilical, que podia variar de um lugar a outro segundo as necessidades locais e o gênio dos arquitetos - é incorreto pensar que o estilo basilical fosse único. Em Roma, não somente a sede episcopal era uma grande basílica, mas muitos tituli reconstruíram suas igrejas com certa suntuosidade e, por isso, foram escolhidas como lugares onde o bispo de Roma celebrava as grandes festas do Calendário Romano. Esta parece ser também a realidade de muitas dioceses no Império Romano. 


\section{Carta aos Hebreus e o templo ${ }^{19}$}

A melhor reflexão sobre a superação do templo de Jerusalém e de sua liturgia sacrifical encontra-se na Carta aos Hebreus. Trata-se de uma homilia dirigida a uma comunidade cristã em crise de perseverança por inseguranças internas (medos, desânimos, cansaço ou dúvidas) e pelas dificuldades externas (violência, boicote econômico e social). A Carta aos Hebreus contrapõe o sacrifício de Jesus aos sacrifícios oferecidos no templo da antiga aliança e, a partir disso, percebe-se a nova concepção de templo, ou seja, de lugar da habitação e manifestação de Deus e, portanto, sua importância salvífica.

Toda a teologia da Carta aos Hebreus está a serviço da cristologia. Aos cristãos desanimados, ela lembra que o sacrifício de Jesus é infinitamente superior aos sacrifícios oferecidos no templo. Estes são incapazes de salvar o homem, apenas são uma imagem do verdadeiro sacrifício oferecido por Jesus no altar da cruz e, portanto, o sacerdócio hebraico é também uma imagem do verdadeiro sacerdócio do Cristo. A lógica da carta reside no fato de que o real, o sacrifício de Cristo, é superior à prefiguração. Por esse motivo, o autor não se detém em descrever o templo detalhadamente, mas se satisfaz em dar uma breve descrição daquela parte onde o rito sacrifical se desenvolvia, a saber, as duas tendas:

Pois a primeira aliança tinha um ritual para o culto e um templo terrestre. De fato, foi instalada uma tenda, uma primeira tenda denominada Santo, onde estavam o candelabro, a mesa e os pães da proposição. A seguir, atrás do segundo véu, encontrava-se uma tenda, chamada Santo dos Santos, com um perfumador de ouro e a arca da aliança toda recamada de ouro; dentro desta, um vaso de ouro que continha o maná, a vara de Aarão que florescera e as tábuas da aliança. Por cima da arca, os querubins de glória cobriam com sua sombra o propiciatório. Mas não vem ao caso entrar aqui em pormenores (Hb 9:1-5).

19. Esse item e os desenhos nele contidos foram inspirados pela conferencia proferida pelo jesuíta esloveno Prof. Dr Mark Ivan Rupnik no $11^{\circ}$ Encontro Nacional de Arquitetura e Arte Sacra, realizado em Curitiba pela Conferência Nacional dos Bispos do Brasil (CNBB) e pela Pontifícia Universidade Católica do Paraná (PUCPR) em 20 de setembro de 2017. 
Os cristãos compreenderam que é a liturgia que faz o espaço. É preciso compreender a liturgia como uma passagem. Os cristãos se reúnem e pela eucaristia entram na casa do Pai. No Santuário do santuário, na Jerusalém celeste, na Praça de Ouro, do Apocalipse 21,22. É ai que se convoca todo o Corpo de Cristo, de Abraão a nós. Na anáfora ${ }^{20}$ armênia, por exemplo, até as crianças que ainda não nasceram são convocadas. Todos os que pertencem a Cristo são convocado a uma única assembleia. E juntos cantam: "Santo, Santo, Santo, Senhor Deus do Universo", sintonizados à musica celeste. Não são os cristãos que fazem a festa ao Senhor, "bendito os que vêm em nome do Senhor", os cristãos são convidados do Senhor à casa do Pai. A Eucaristia é o ingresso no Reino e começa quando os cristãos deixam suas casa domingo para ir à celebração eucarística e termina no Escathon. Na casa do Pai entram, "por Cristo, com Cristo, em Cristo", a vós Deus Pai estão todos aqui e agora sim podem dizer: "Pai Nosso que estais no céu". Ao voltar, estão com os olhos limpos por tudo o que viram no santuário em comunhão, conhecendo o Pai, e recebendo o que ofertaram, o Corpo de Cristo.

A liturgia é uma passagem de um espaço a outro. De uma história ordinária a uma história santa, da criação inicial a uma nova criação, de uma realidade de pecado a uma realidade santa. Os cristãos se recordaram de Moisés quando Deus lhe pede para construir a tenda do encontro. A carta aos Hebreus, capítulos 8, 9 e 10, diz que Deus fez esse gesto a Moisés para dar a chave de leitura de toda obra de Cristo e de tudo o que é a Igreja. O que acontece no monte? Deus Ihe diz que deve fazer uma primeira tenda, onde os sacerdotes e o povo entram e fazem a liturgia. Mas há ao lado uma segunda tenda, que é a habitação de Deus, o Santo dos Santos, a verdadeira casa de Deus que Moisés não viu, porque Deus não permitiu, deu-lhe apenas o modelo, mas modelo não é o original.

20. Palavra grega que advém de (ana-fero). O que elevamos a Deus é louvor ou o sacrifício. É o nome que recebe nas liturgias orientais o que chamamos de Oração Eucarística. 


\section{As duas tendas de Moisés}

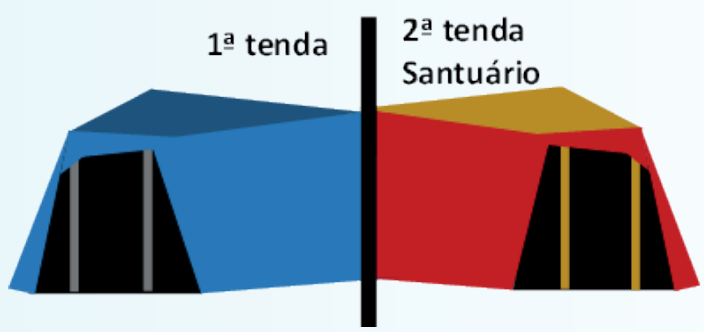

Figura 4: as duas tendas de Moisés.

A primeira tenda é a humanidade, mas o homem não pode caminhar para Deus, não pode sair dele mesmo. Pode lançar-se em um mundo ideal, um mundo metafisico que acaba em moralismo e que não leva um quilo de humanidade ao Reino. Entre as duas tendas há uma cortina que representa o pecado e a morte, ninguém jamais superou essas duas coisas. Mas, simbolicamente, uma vez ao ano, o sumo sacerdote entra nesse espaço que não é o verdadeiro santuário, mas um modelo.

O que representa a 1 a tenda?

Carta aos Hebreus

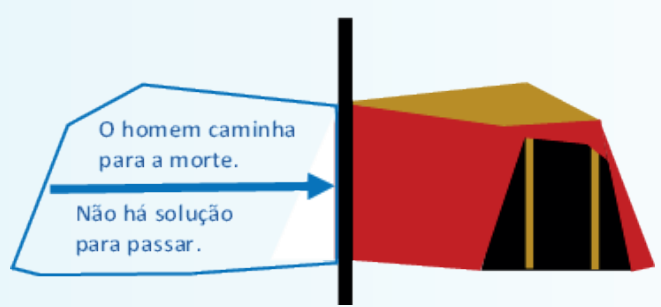

Figura 5: representaçãa da primeira tenda.

A carta aos Hebreus diz, refletindo sobre essa estrutura veterotestamentária, que na segunda tenda habita o Pai que enviou seu Filho, que atravessou o céu e se fez Homem. Na Septuaginta, tradução grega da Bíblia, há uma belíssima expressão que fala da humanidade como uma tenda. Deus criou o homem e depois entra na sua tenda, se fazendo homem. Deus entra como Homem e vai em direção a essa cortina. 


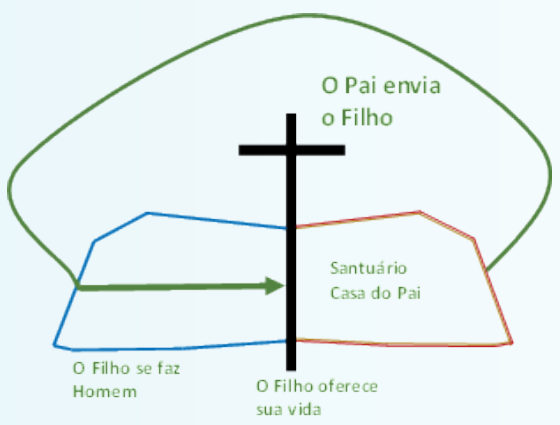

Figura 6: 0 simbolismo do Filho na tenda.

Os capítulos 4 e 5 da Carta ao Hebreus descrevem dramaticamente uma liturgia de gritos e lágrimas para ser liberado da morte, solidário a todos os homens, passando por tudo que a humanidade passa. A carta fala de sacrifícios, gritos e sofrimentos, porém, Deus deu a seu Filho a vitória, vencendo a morte. Está nos Evangelhos que ao ser morto, o véu do templo se rompeu, pois, só o Filho sabia que além do véu, ou seja, da morte, está o Pai. Por isso o pai o envio - importante notar como Cristo insiste em muitas passagens que o Pai o envio - porque assim o Pai o ressuscita. Essa abertura é a liturgia.

Essas duas realidades juntas, as duas tendas, formam o Cristo, a unidade, verdadeiro Deus e verdadeiro Homem. Tudo o que é divino pode vir em direção ao homem e tudo o que é humano tem acesso a Deus. Mas a Igreja ensina que essa unidade é a igreja e que não coincide perfeitamente com o Cristo, mas é o ingresso ao Reino, e a liturgia é essa passagem.

O que é o ofertório? O cristão leva ao altar pão e vinho, as suas ofertas ao universo, à terra e seu trabalho, depois desce o Espirito Santo, - momento da Epíclese - que transforma a oferta em Corpo de Cristo. Não é uma oferta pura, o Espírito Santo a torna Corpo de Cristo e logo após a consagração, entra-se na memória da Páscoa de Jesus, participa-se da sua morte na cruz, e o que sucede? Quando toda a humanidade de Cristo penetrada da vida do Filho se torna um dom, e toda humanidade se torna um dom, uma oferenda 
perfeita, o que acontece? Ele morre como Cristo e o Pai o ressuscita. A oferta do cristão entrou no Corpo de Cristo. O Corpo de Cristo eucarístico é constituído pelas ofertas. Essa oferta ao ser transportada é a princípio ordinária, depois se transforma em Cristo ressuscitado. O Corpo de Cristo é constituído do pão e do vinho do cristão que celebra, isto é, do seu trabalho. Não há Cristo eucarístico sem o cristão. Na eucaristia o cristão não se imagina no Reino, ele realmente está no Reino, porque minha oferta passou, minha vida, meu trabalho, meu cansaço, pois tudo isso foi ofertado. Tudo isso passou e isso deve ser respeitado na edificação de uma igreja.

Respeitar essa estrutura teológica - a igreja ter visivelmente essas duas tendas - essa foi a conquista dos cristãos dos primeiros séculos. A igreja deve ter visivelmente essas duas tendas: humanidade e divindade que se transformam em uma Pessoa, Cristo, a unidade. Deve ser visível na estrutura a passagem de uma para outra e ao mesmo tempo deve ser visível a unidade, porque Cristo é uma só Pessoa. Essa deve ser a inspiração para se construir uma igreja. Esse é um fundamento sobre o qual não há objeções nem objeto para discussões, essa é a fé dos cristãos.

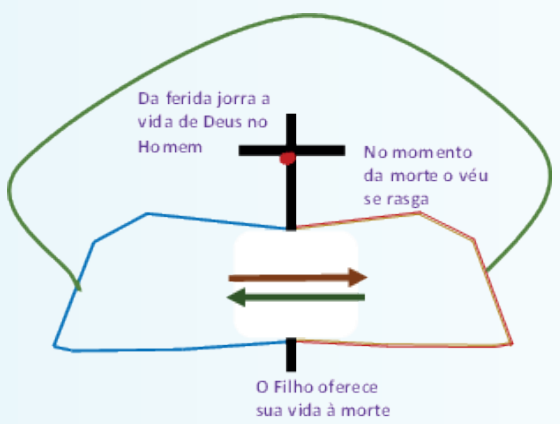

Figura 7: 0 simbolismo da unidade das duas tendas.

Na Basílica de Santa Maria Madalena em Veselay, França, no pórtico havia no início São João Batista e na nártex a memória do batismo que exprime a vida nova. No solstício de verão, há pontos de luz no chão que traçam o caminho para a casa do Pai, que é o Altar, que é Cristo, na semana de 24 de junho, quando se celebra São João Batista. Os construtores elaboraram 
o espaço inspirados na liturgia, a arquitetura e a arte serviam ao Cristo. No solstício de inverno, na semana do Natal, o sol reflete nos capitéis norte, nos quais estão representadas a fauna e a flora, a Criação, a qual só se entende sob a luz de Cristo, e cenas do Antigo testamento, que só se entendem à luz de Cristo.
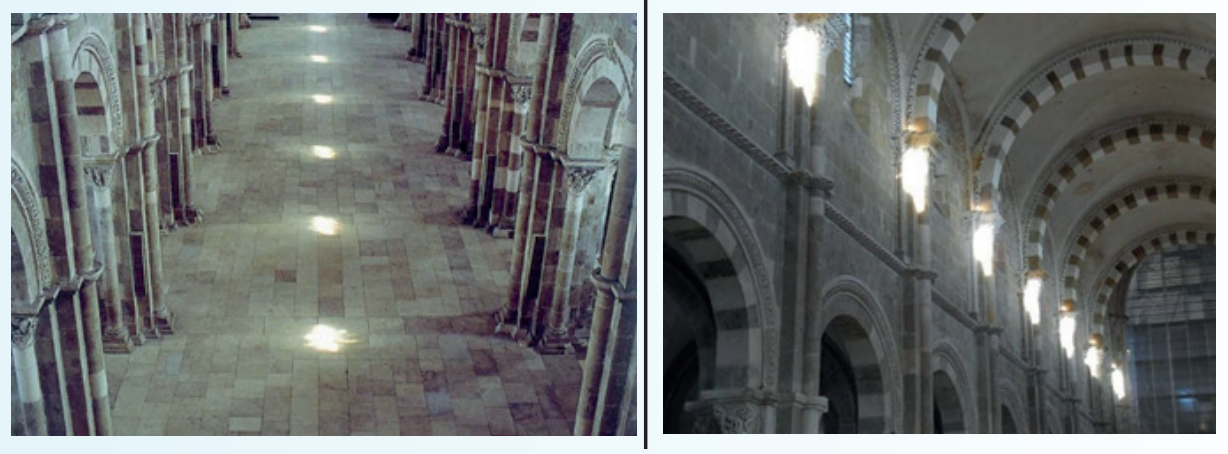

Figuras 8 e 9: trilha de luz durante 0 solstício de verão e reflexo nos capitéis no solsticio de inverno na Basilica de Santa Maria Madalena em Veselay.

Outro exemplo é a Basílica de Monreale na Sicília, Itália, construída na mesma época que Veselay. Um espaço que exprime o Corpo de Cristo, e Cristo é a Cabeça desse Corpo, a Esposa e o Esposo. O Corpo de Cristo, a humanidade revela todo o mistério do pai, do Filho, do pecado e da Redenção. Cristo é apresentado como o sacerdote dos bens vindouros, dos quais o culto da antiga aliança é apenas uma sombra. O sacrifício de Cristo não é menos real do que os que outrora eram oferecidos no templo, pois houve efetivamente derramamento de sangue:

Foi através de uma tenda maior e mais perfeita, que não é obra das mãos - isto é, que não pertence a esta criação -, e pelo sangue, não de bodes e novilhos, mas por seu próprio sangue, que ele entrou de uma vez para sempre no santuário, e obteve a libertação definitiva $(\mathrm{Hb}$ 9:11-12). 


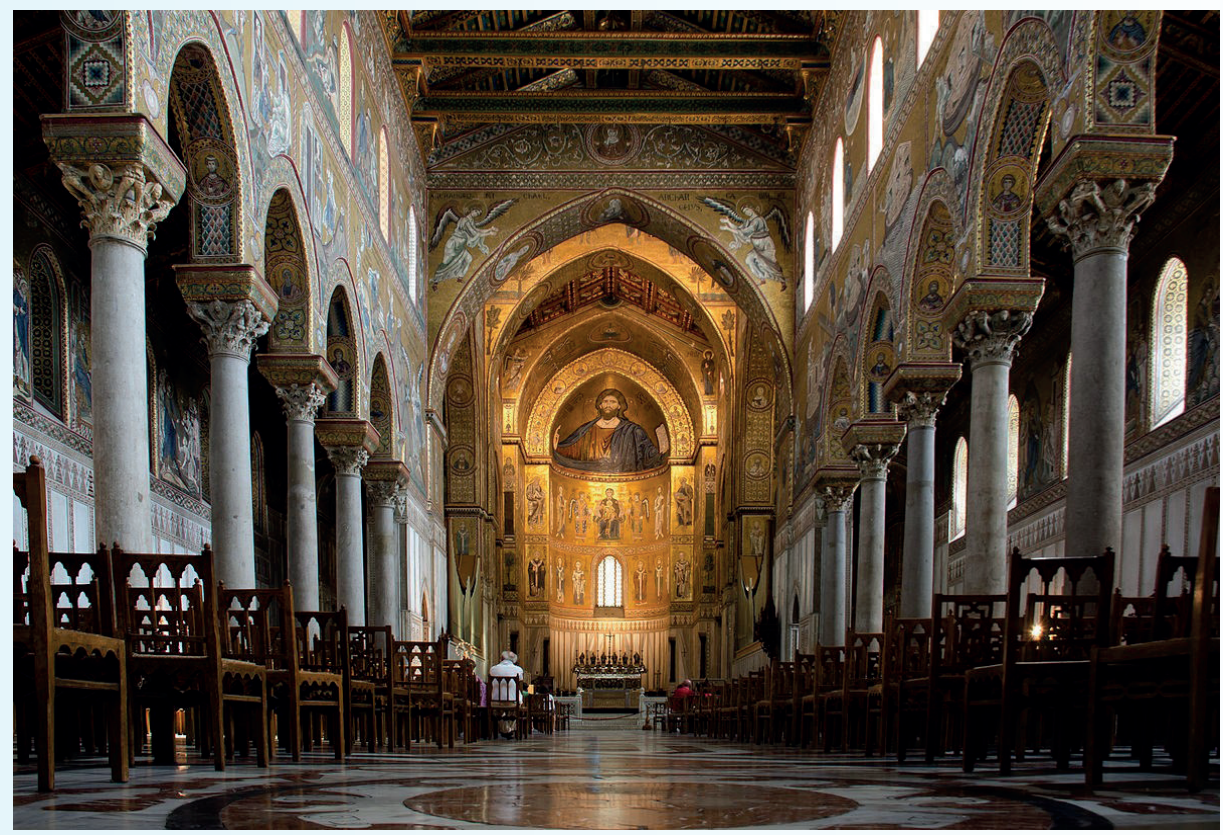

Figura 10: Cristo na Basilica de Monreale na Sicilia.

O autor pretende assim demonstrar a caducidade da liturgia do templo, "... se o sangue de bodes e de novilhos, e se a cinza da novilha, espalhada sobre os seres ritualmente impuros os santifica, purificando seus corpos, quanto mais o sangue de Cristo que, pelo espírito eterno, se ofereceu a si mesmo a Deus como vítima sem mancha, há de purificar a nossa consciência das obras mortas para que prestemos culto ao Deus vivo." (Hb 9:13-14). A antiga aliança foi então substituída por uma nova, muito superior, porque não é mais o esboço, mas a realidade mesma "Eis porque ele é mediador de nova aliança.(...) Portanto se as copias das realidades celestes são purificadas com tais ritos, é preciso que as próprias realidades celestes sejam purificadas com sacrifícios bem melhores que estes!" (Hb 9:15-23), e esta nova aliança foi selada com o próprio sangue de Cristo, derramado de uma vez por todas. Tratase, pois, de um sacrifício único, sem repetição (Hb 10:1-18).

Os cristãos não precisam mais de um templo para oferecer sacrifícios a Deus, pois " Ora, onde existe a remissão dos pecados, já não se 
faz oferenda por eles." (Hb 10:18). A eficácia do sacrifício pessoal de Cristo dispensa tais sacrifícios e, portanto, um templo para oferecê-los. Cristo, tendo superado a primeira tenda, garante aos cristãos o acesso direto ao santuário verdadeiro, isto é, os céus onde Deus habita, e esse acesso se dá pela fé: "a fé é a garantia dos bens que se esperam, a prova das realidades que não se vêem." (Hb 11:1).

Segundo a Carta aos Hebreus, o verdadeiro templo não está aqui neste mundo, o templo que aqui existia era apenas uma cópia do verdadeiro, que é a morada do Altíssimo. A antiguidade cristã nos demonstra que o espaço litúrgico não é apenas um abrigo para a reunião do povo, Christi fideles, mas é espaço mistagógico, que ajuda a cada cristão a contemplar na arquitetura do lugar de culto de sua comunidade o mistério de seu Senhor e de sua Igreja.

\section{O Concílio Ecumênico Vaticano II}

O Concílio Ecumênico Vaticano II foi consagrado como o maior evento católico do século XX. Convocado pelo Papa João XXIII em 25 de dezembro de 1961 e aberto oficialmente em 11 de outubro de 1962, foi encerrado pelo Papa Paulo VI em 8 de dezembro de 1965. Foram quatro anos de encontros, reflexões, debates e conclusões. Nesse elenco doutrinário e pastoral se encontra o indispensável para a atualização e a renovação da Igreja, maior objetivo do Concilio. Os documentos do Vaticano II exigiriam estudo, prática, compreensão e iniciativa não só da hierarquia, como também dos cristãos. Durante a sua realização, e depois da sua conclusão, houve aplausos, mas não faltaram críticas. Foram muitos os que se dispuseram a pôr em prática suas conclusões, mas também não faltou oposição, o que indica que na Igreja há lugar tanto os que olham para frente como os que se prendem ao passado, rejeitando qualquer inovação ${ }^{21}$. Segundo Libânio,

21. Cf. Dom Geraldo Majella AGNELO, Arcebispo Emérito de Salvador. Disponível em: www.paulus.com.br/ institucional/odomingopalavra/9-de-dezembro-2o-domingo-do-advento. Acessado em 4 de jan. de 2013. 
O modelo de Igreja-sociedade perfeita, cujos contornos visíveis e jurídicos se deixavam identificar, eclipsa-se diante da visão de uma Igreja-mistério que vem da Trindade, é-lhe ícone e orienta-se para ela. Recuperase este aspecto de mistério, seja superando a visão objetivista pré-moderna, como revalorizando as fontes teológicas através das pesquisas históricas ${ }^{22}$.

As declarações do magistério sobre a arte nunca foram tão numerosas na história bimilenar da Igreja quanto no curso da segunda metade do século $X X$, principalmente, desde o encerramento do Concílio. Porém, as declarações do próprio Concílio sobre as artes - arquitetura, literatura, poesia, música e belas artes - foram raras. As decisões conciliares estão concentradas, em sua maior parte, na Constituição sobre a liturgia, Sacrosanctum concilium. Pouco desenvolvidas, elas são, todavia, de grande valor e revelam uma audácia de concepção. ${ }^{23}$

\subsection{O Vaticano II e as artes}

Há três textos significativos da reflexão da Igreja sobre a sua relação com a arte contemporânea. Trata-se de duas constituições do Concílio Vaticano II - uma sobre a liturgia, Sacrosanctum Concilium e outra, Gaudium et Spes, sobre a relação da Igreja com o mundo contemporâneo, e algumas palavras que, entre a aprovação destes dois documentos, Paulo VI dirigiu aos artistas, antes mesmo do término do Concílio.

No Sacrosanctum concilium, a Igreja se diz amiga das belas artes e solicita seu ministério. Ela não se satisfaz em sujeitar-se à sua evolução e esperar que os artistas pudessem apresentar propostas. A Igreja tem como objetivo mais que apenas acolher obras novas ou preservar as antigas de serem descartadas quando muda o gosto (124). Ela não vai se limitar ao papel de comandatária, pretende também formar os

22. J.B. LIBANIO, O Concilio Vaticano II e a Modernidade. Disponível em: www.jblibanio. com.br/modules/mastop_publish/?tac=101. Acessado em 26 de jan. de 2013.

23. Cf. François BOESPFLUG, Dieu et ses images: une histoire de l'Eternel dans l'art, p. 445. 
artistas e vai até reivindicar para si a competência e o direito de julgar suas obras (124 e 126). Como "julgar" entenda-se o direito de avaliar se a obra é aceitável em função do seu acordo com a fé, a verdadeira piedade, a tradição. O Concílio concede às comissões nacionais de liturgia diocesanas de arte sacra o cuidado desse julgamento (126). A Igreja não elegeu nenhum estilo (123), o que significa que não vai privilegiar nenhum. Todos os estilos podem servir ao rito, mas não serão aceitos sem crítica (126). A Igreja assegura que admite sem reticências os gêneros típicos de cada época e de cada região desde que sirvam aos edifícios e ritos sagrados com o respeito e honra que Ihes são devidos. Ela quer continuar sendo "amiga das artes" (122), mas uma amiga exigente, pois essa acolhida das inovações em todos os gêneros não significa que ela assine em branco. Ela lhes dá lugar, contanto que sejam capazes de suscitar obras em harmonia com a prática litúrgica e sua doutrina, esse é o ponto chave ${ }^{24}$.

Em 7 de maio de 1964, portanto antes do término do Concílio, Paulo VI dirige-se de forma corajosa aos artistas. Lembra a responsabilidade da lgreja no distanciamento da arte do seu tempo, estimula os artistas a obter a sólida informação religiosa necessária à arte litúrgica e manifesta o desejo de retomar o diálogo com os artistas, tão fecundo no passado.

Finalmente, a Constituição Pastoral Gaudium et Spes (1965), num capítulo dedicado à questão do diálogo com a cultura, encoraja a Igreja a aderir às correntes de arte contemporânea que, na sua qualidade de expressão do humano, ajudam a enraizar e exprimir a fé. Trata-se de uma Constituição pastoral sobre a Igreja no mundo atual. Este documento, no entanto, é prudente no que diz respeito à arte litúrgica, convidando a se promover uma "nobre beleza" sem se referir a nenhum estilo em particular, conforme o n.123 do documento Sacrosanctum Concilium, onde também se declara que a Igreja admite todo tipo de arte:

24. Cf. François BOESPFLUG, Dieu et ses images: une histoire de l'Eternel dans l'art, p. 445 . 
A lgreja deve reconhecer as novas formas artísticas, que se adaptam às exigências dos nossos contemporâneos. Sejam admitidas nos templos quando, com linguagem conveniente e conforme as exigências litúrgicas levantam o espírito a Deus. Deste modo, o conhecimento de Deus é mais perfeitamente manifestado; a pregação evangélica torna-se mais compreensível ao espírito dos homens e aparece como integrada nas suas condições normais de vida. (GS 62)

O Movimento Litúrgico e o Concilio Vaticano II mudaram a concepção da liturgia e, portanto, a concepção das igrejas. No domínio católico, não é mais o sacerdote que leva o povo a Deus e o representa diante d'Ele; o povo reunido ante o altar e às vezes em torno dele, participa plenamente da liturgia. É esse o grande desafio dos arquitetos e artistas sacros pós-Vaticano II.

\section{Cláudio Pastro: um artista pós-Concílio}

Cláudio Pastro comparava seu trabalho ao do que pode ser considerado o primeiro artista sacro cristão: o fóssore. No ano de 2008, na palestra "A ferida da Beleza", Pastro diz que enquanto artista sacro, artista cristão, vê a si mesmo como um bom fóssore: aquele coveiro das catacumbas, cuja função era preparar o pré-defunto antes de morrer, confortar a família, preparar a cova, até a "festa" da passagem, o velório, de modo a conduzir esta alma ao paraíso. Insistia que a função de um artista sacro é, com muita responsabilidade, ser um mistagogo, ou seja, levar primeiramente a si mesmo e, depois, os demais para o paraíso. Paraíso que, nas palavras de Pastro, acontece a cada celebração litúrgica, quando o céu desce à terra, antecipando a Jerusalém Celeste, e é para isso que ele prepara o espaço sagrado.

O artista sempre se inspirou nos primitivos cristãos, nos traços e cores da arte românica e na dignidade hierática e nobre da arte do ícone bizantino, em que os pobres apóstolos e santos (os humanos) se revestem da beleza de Deus. 
Nas declarações conciliares referentes à arte, os depoimentos feitos por Pastro e sua autodenominação como artista "pós-conciliar" de arte sacra ficam transparentes. Podem-se distinguir alguns aspectos referentes à arte no Concílio presentes na obra do artista tais como a volta às fontes, a nobreza da arte, o lugar que ocupa na fé cristã, a arte como ministério, o serviço à liturgia, a relação entre a liberdade da arte e a inculturação.

A "volta às fontes" estava entre as intenções subjacentes que caracterizaram o Concílio, com o intento de redescobrir as riquezas espirituais, doutrinárias e litúrgicas dos primeiros tempos da Igreja. Anterior ao Concílio, no Movimento Litúrgico já se clamava por uma liturgia renovada que atendesse aos novos tempos. Pastro exorta o ad Fontes, a volta do Senhorio de Cristo, a qual interpreta como a intenção fundamental do Vaticano II.

A arte havia se tornado cada vez mais acadêmica, mais secular, arte com temas religiosos, mas não arte sacra. O devocionismo levou os santos ao centro de muitos santuários ${ }^{25}$ no lugar de destaque, o lugar central, que seria do Cristo, o Senhor ressuscitado. A proposta ad fontes vai permitir resgatar a arte do subjetivismo da livre expressão artística e dirigir a ação litúrgica ao Senhor Ressuscitado. Como diz Pastro, "e a arte como expressão do belo, da presença, da glória de Deus em nosso meio, não poderia ser a mesma dos últimos séculos"26.

A arte no Concílio é apresentada como nobre, ou seja, é digna de contribuir para a realização da liturgia. O que torna a arte sacra, em outros termos, é a sua capacidade de se colocar a serviço do culto. Trata-se de uma sacralidade do tipo cultual e não de sacralidade natural. Parece que na expressão "nobre simplicidade" o Vaticano II também não se esqueceu da suntuosidade que provocou um debate na época da

25. Santuário é o mesmo que presbitério: lugar mais importante de todo espaço celebrativo, por isso deve ser de preferência visível a toda assembleia. Nele ficam: altar, sédia, ambão, cruz processional, relíquia do santo ou mártir.

26. Cláudio PASTRO, Guia do espaço sagrado, p. 13. 
Contrarreforma. A arte sacra, diz Boespflug, constitui

O mais alto nível que pode alcançar a arte religiosa e a arte em geral: aqui prevalece uma graduação que vai na contramão da tendência que prevaleceu desde o século XIX nos meios da arte e cultura, onde a arte religiosa foi geralmente considerada como um grau inferior da arte, ao ponto que os artistas não aceitavam, de bom grado, ser artista religioso, pois tinha um aspecto restritivo e pejorativo. ${ }^{27}$

Por isso, é a forma, para Pastro, quem faz a arte sacra, não o tema. Quando faz o projeto ou cuida do programa iconográfico, ele recomenda que se coloque um Pantocrator na abside ou na parede frontal do santuário da igreja: Cristo é o celebrante, o sacerdote preside. Diz ele:

Porque celebramos unicamente o mistério pascal, a iconostase é um belo e proveitoso elemento litúrgico. Como centro é o Cristo, recomenda-se pintar um Pantocrator. É o Cristo, Mestre e Senhor, com a Escritura em sua mão esquerda contendo uma frase-mantra para a comunidade, por exemplo: "Eu sou o Caminho, a Verdade e a Vida" ou "Eu faço nova todas as coisas ${ }^{28}$."

\section{Marko Ivan Rupnik o artista da Beleza}

O religioso jesuíta e artista esloveno Marko Ivan Rupnik (Salloga d'Idria, 28 novembro de 1954), revela que a sua primeira inspiração é a Palavra de Deus e, como Cláudio Pastro, tem como guia principal na arte litúrgica o Concílio Vaticano II, que convida a reler aquele grande período que foi o Primeiro Miênio, a era patrística e a procurar iluminação nos fortes períodos da arte dos cristãos, como o românico, o primeiro bizantino.

Rupnik considera que a cultura ocidental deu precedência à verdade e ao bom. "Certamente negligenciou o belo ao reduzi-lo a algo puramente decorativo e não absolutamente necessário como o verdadeiro

27. François BOESPFLUG, Dieu et ses images: une histoire de l'Eternel dans l'art, $p$. 445.

28. Cláudio PASTRO, Guia do espaço sagrado, p. 79. 
e o bom", afirmou em entrevista publicada no semanário "Igreja Viva", suplemento do "Diário do Minho", da arquidiocese de Braga ${ }^{29}$.

O artista sacro e jesuíta é especialista nos pensadores russos do fim do século XIX e do século XX que refletiram, entre outros assuntos, sobre a beleza, como Vladimir Solov'ëv, Pavel Florenskij e Nicolas Berdiaev. Solov'ëv sustenta que um bem que não se torna beleza é um perigo para o homem, a ditadura do bem é a suprema expressão do mal. Da mesma forma, uma verdade que não se torna beleza é um monstro que destrói o homem. Em nome da verdade muitos morreram e em nome de ideias humanistas a época moderna matou dez milhões de pessoas. Solov'ëv ainda afirma que a ideia que não é capaz de encarnar-se como beleza demonstra sua impotên$\mathrm{cia}^{30}$. Segundo Rupnik, o padre e mártir Pavel Florenskij fez a melhor síntese da beleza: "a Verdade manifestada é o amor - Cristo - o amor realizado é a beleza. A beleza realizada é a manifestação da verdade como amor ${ }^{31 ”}$.

Quanto à arte paleocristã, Rupnik em palestra na PUC-PR em setembro de 2017, sublinhava que a arte cristã começou nas catacumbas, no subsolo, lugar da morte, na contramão da arte clássica greco-romana da época, abandonando completamente a ideia de perfeição. A arte cristã nasceu simbólica e deve ser simbólica ${ }^{32 !}$

\section{Cláudio Pastro e Marko Ivan Rupnik}

Pastro e Rupnik nunca se encontraram, porém, a arte de ambos embora diferentes quanto ao processo - Rupnik e sua equipe trabalham com mosaico e Pastro usava outras técnicas - os dois artistas têm muito em comum: a arte é um serviço litúrgico, deve ser simbólica, levar o fiel

29. Disponível em: http://www.snpcultura.org/cultura_ocidental_negligenciou_o_belo_ marko_rupnik.html. Acessado em 12 de jul. de 2018.

30. Cf. Marko Iva Rupnik. L'autoritratto della chiesa, arte, bellezza e spiritualità. Bologna. EDB Lampi, Centro Editoriale Dehoniano, 2015, p. 18.

31. Cf. Marko Ivan Rupnik. Via della bellezza sapienza di vita. Museu della Basilica, Santa Maria delle Grazie, Quaderni 5. Firenze: Edizione Feeria, 2007. p. 19

32. $11^{\circ}$ Encontro Nacional de Arquitetura e Arte Sacra, realizado em Curitiba pela Conferência Nacional dos Bispos do Brasil (CNBB) e pela Pontifícia Universidade Católica do Paraná (PUCPR). Segunda palestra do dia 20 de set. de 2017. 
à contemplação, sentir o desejo de ajoelhar-se e rezar. Diferente da arte Renascentista, que leva ao deslumbramento pelo virtuosismo do artista que a criou.

São críticos do Renascimento enquanto arte para a Igreja, pois nos últimos séculos da modernidade, a característica fundamental sob o aspecto espiritual foi do maleficio vindo a partir do Renascimento de conviver com o paganismo, a tentativa de fazer conviver Cristandade e Antiguidade pagã, fazer uma relação dessas duas realidades. Ambos também concordam que o Barroco foi uma tentativa de voltar à arte sacra que fracassou.

Em seus textos os dois artistas sacros insistem que a Presença do Invisível só é percebida em uma cultura do símbolo, em que "as coisas e acontecimentos" indicam outra realidade. Em um universo limitado pelo visível, não há a ação do Mistério, mas apenas a ação humana, que em si é fraca e limitada, quando não usurpadora.

Os símbolos são sinais repletos, contém toda realidade. Desde a iconografia cristã primitiva, os símbolos que entraram na sua configuração tornaram-se tradicionais e se repetem, não sem algumas variantes, mas, segundo um estilo convencional, segundo cânones que evoluíram consideravelmente tanto no Oriente como no Ocidente.

Os símbolos cristãos estão culturalmente situados e têm como sua primeira e fundamental raiz a Tradição bíblica. O profeta Isaías faz lahweh dizer: "Eu sou o primeiro e o último, fora de mim não há Deus." (Is 44:6). Jesus Cristo, Alfa e Ômega, exprime por sua vez a totalidade do tempo, do início ao fim da Criação. Tudo é dominado por Ele. O autor do Apocalipse cita o mesmo texto de Isaias e acrescenta, dirigindo-se aos fiéis de cultura grega, uma fórmula equivalente valendo-se do simbolismo das letras. Sendo alfa e ômega, primeira e última letras do alfabeto, faz o Senhor dizer: "Eu sou Alfa e Ômega, Aquele que é, Aquele que era e Aquele que vem, o Todo Poderoso" (Ap 1:8). Após a visão de Deus sobre seu trono de glória, presidindo a nova criação, João o ouve falar: "eis que faço nova todas as coisas" [...] "Eu sou 
Alfa e Ômega, o Princípio e o Fim" (Ap 21:5-6). Enfim, no capítulo 22, que encerra o Apocalipse, é o próprio Cristo que assume os títulos antes reservados a Deus: "Eu sou alfa e Ômega, o Primeiro e o Último, o Princípio e o Fim" (Ap 22:13). ${ }^{33}$

Pastro, a começar pela década de 80 do século passado, entendeu ainda jovem o chamado do Concilio Vaticano II. Na contracorrente dos artistas contemporâneos, que exaltavam a novidade de estilos artísticos e arquitetônicos e, em uma cultura que admira e está habituada ao barroco, inspira-se nos ícones, na arte bizantina, na simplicidade do românico e em alguns modernistas, levando às paredes das igrejas a Biblia pauperum e ao presbitério o Cristo Pantocrator. Causou estranhamento e muitas críticas, mas deixou muita beleza, preparou de forma sublime muitos espaços sagrados no mundo e nas igrejas do Brasil, sobretudo no magnífico Santuário Basílica de Nossa Senhora Aparecida no Estado de São Paulo.

Ao que tudo indica, há um projeto em andamento para que Rupnik faça a parte externa do Santuário de Aparecida. Se acontecer, os dois artistas estarão juntos e eternizados em suas obras.

\section{Referências}

BELTING, Hans. Image et culte: une histoire avant l'époque de l'art. Paris: Les Éditions du Cerf, 2007.

BAUDRY, Gérard-Henry. Les symboles du christianisme ancien: ler-VII siècle. Paris: Édition du Cerf, 2009.

BESANÇON, Alain. L'image interdite: une histoire intellectuelle de l'iconoclasme. Paris: Gallimard, 2000. (Collections folio/essais)

BOESPFLUG, François. Dieu et ses images, une histoire de l'Eternel dans l'art. Paris: Éditions Bayard, 2008.

ELIADE, Mircea. O mito do eterno retorno. Lisboa: Edições 70, 1968. (Perspectiva do homem 5)

33. Cf. Gérard-Henry BAUDRY, Les symboles du christianisme ancien: Ier-VII siècle, p. 57-58. 
EVDOKIMOV, Paul. L'Art de I'Icône: Théologie de la beauté. Paris: Desclée de Brouwer, 1972.

GOVEKAR, Natasa. (a cura di). II rosso della piazza d'oro: Intervista a Marko Ivan Rupnik su arte, fede ed evangelizzazione. Roma: Lipa Edizione, 2013.

IRVIN, Dale T.; SUNQUIST, Scott W. História do movimento cristão mundial: do cristianismo primitivo a 1453. São Paulo: Paulus, 2004. v. I

JEDIN, Hubert. Manual de historia de la Iglesia I. Barcelona: Herder, 1966. p. 418-419.

LACOSTE, Jean-Yves (dir.). Dicionário crítico de teologia. São Paulo: Edições Paulinas, Edições Loyola, 2004.

OUSPENSKY, Léonide ; LOSSKY, Vladimir. Le sens des icônes. Paris: Les Éditions du Cerf, 2003.

OUSPENSKY, Léonide. La théologie de l'icône dans l'Église Orthodoxe. Paris: Les Éditions du Cerf, 2007.

PASTRO, Cláudio. Arte Sacra: o espaço sagrado hoje. São Paulo: Edições Loyola, 1993.

PASTRO, Cláudio. Guia do espaço sagrado. 4. ed. São Paulo: Edições Loyola, 2007.

PASTRO, Cláudio. A arte no cristianismo: fundamentos, linguagem, espaço. São Paulo: Paulus, 2010.

RUPNIK, Marko Ivan. Via della bellezza sapienza di vita. Museu della Basilica, Santa Maria delle Grazie, Quaderni 5. Firenze. Edizione Feeria, 2007.

RUPNIK, Marko Ivan. L'autoritratto della chiesa, arte, bellezza e spiritualità. Bologna. EDB Lampi, Centro Editoriale Dehoniano, 2015.

ZEVI, Bruno. Saber ver a arquitetura. São Paulo: Martins Fontes, 2009 (Mundo da Arte).

Sites: Dom Geraldo Majella AGNELO, Arcebispo Emérito de Salvador. Disponível em: www.paulus.com.br/institucional/odomingopalavra/9-de-dezembro-2o-domingo-do-advento. Acessado em 4 de jan. de 2013.

J.B. LIBANIO, O Concilio Vaticano II e a Modernidade. Disponível em: www.jblibanio. com.br/modules/mastop_publish/?tac=101. Acessado em 26 de janeiro de 2013. 
RUPNIK, Mark Ivan. La belleza, lugar del conocimiento integral. Disponível em http:// comunicacioninstitucional.ufv. es/wp-content/ uploads/2013/10/Lectio-DHC-Rupnik-.pdf. Acessado em 29 de jun. de 2018.

Cultura ocidental "negligenciou o belo ao reduzi-lo a algo puramente decorativo", diz P. Marko Rupnik. Disponível em: http://www.snpcultura. org/cultura_ocidental_negligenciou_o_belo_marko__rupnik.html. Acessado em 12 de jul. de 2018. 110 Encontro Nacional de Arquitetura e Arte Sacra, realizado em Curitiba pela Conferência Nacional dos Bispos do Brasil (CNBB) e pela Pontifícia Universidade Católica do Paraná (PUCPR). Segunda palestra do dia 20 de setembro de 2017. 